\title{
The Acacia Species with Glandular Glutinous Pods in Southern Africa
}

\author{
by \\ J. H. Ross
}

\begin{abstract}
Arstract
The complex of Acacia species with glandular glutinous pods. consisting of seven species, is endemic to southern Africa. A map showing the distribution of these species is given. A new key to the identification of these species is provided and characters that enable members of the complex to be distinguished from $A$. karroo Hayne are discussed.
\end{abstract}

The South African species of Acacia with glandular glutinous pods were dealt with by Verdoorn in Bothalia 6:153-160 (1951). Recently Brenan in Kew Bull. $21: 480$ (1968) has described yet another species with glandular pods from Mozambique. As there is now an additional species within the complex and. as more material and information has become available since Verdoorn's treatment. it seems worthwhile to re-examine the entire complex in southern Africa.

The complex now consists of seven species. namely, with species enumerated chronologically: A. nebrownii Burtt Davy, A. borleae Burtt Davy, A. permixta Burtt Davy, A. swazica Burtt Davy, A. exuvialis Verdoorn. A. tenuispina Verdoorn and $A$. torrei Brenan. The complex is endemic to southern Africa. The distribution of each species may be seen in Fig. 1.

Fig. I reveals that no species within this complex occurs in the Orange Free State, in Lesotho or in the Cape. The Transvaal has the greatest number of species; of the seven within the complex only $A$. torrei is absent. $A$. exuvialis and $A$. permixta are endemic to the Transvaal. $A$. exuvialis occurring in the eastern portion and $A$. permixta in the western. $A$. torrei is endemic to the Manica e Sofala region of Mozambique. A. borleae occurs in southern Mozambique, the eastern Transvaal, eastern Swaziland and northern Zululand. $A$. swazica occurs in the south-eastern Transvaal, in Swaziland and just south of Abercorn Drift in northern Zululand. A. tenuispina is found in eastern Botswana and in the western and central Transvaal. whilst $A$. nebrownii ranges from South West Africa to Botswana and the northern Transvaal.

This complex of species is taxonomically difficult. The species are all very closely related to one another and to $A$. karroo Hayne and appear to have been derived from $A$. karroo 'stock' during earlier times. It is not clear whether each species was independently derived from the ancestral stock or whether some of the species have given rise to others. Each species seems to have different habitat preferences, the different species being possibly the outcome of differing environmental conditions acting upon a common or similar gene pool. Some specimens cannot be referred either to $A$. karroo or to $A$. tenuispina with 


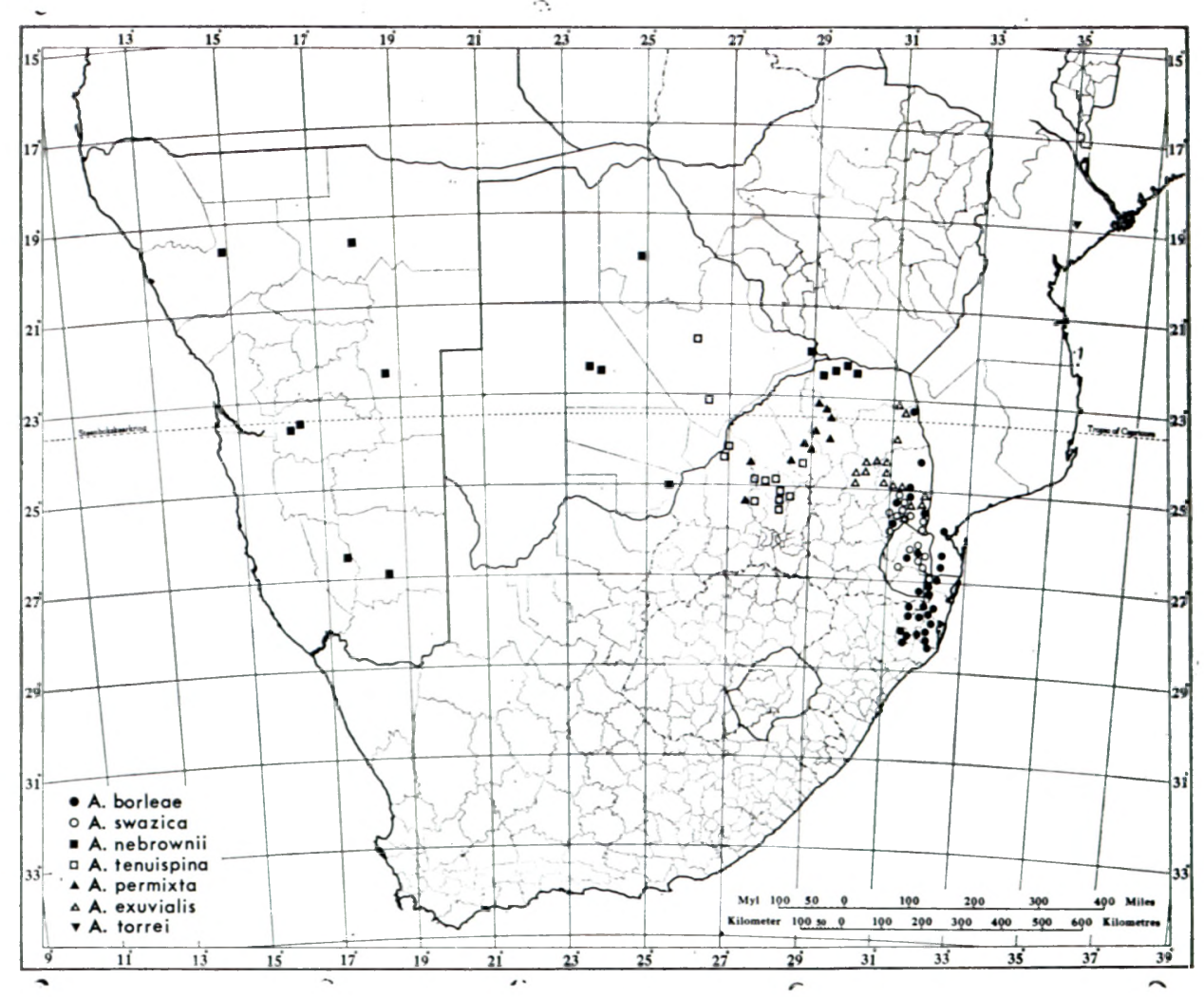

Fig. 1.- The known distribution of the Acacia species with glandular glutinous pods in Southern Africa.

certainty. For example, Codd 7047 (PRE) from north of Pienaars River (Grid Reference: 2528 AB Pretoria) was described by the collector as "possibly a hybrid between $A$. karroo and A. tenuispina." Some plants from the Springbok Flats agree vegetatively with $A$. tenuispina, but lack glandular pods and are therefore hesitantly referred to $A$. karroo. The two species may well hybridize but this requires careful field studies.

Apart from certain specimens referred to above as being possible intermediates between $A$. karroo and $A$. tenuispina, each of the species can usually be distinguished from $A$. karroo fairly easily. The species differ from $A$. karroo in that they are usually small, slender plants and are smaller in all of their parts. With the exception of $A$. borleae and $A$. torrei the remaining species have typically fewer pinna and fewer leaflet pairs than $A$. karroo. The young branchlets, leaf petioles, rachides and rachillae are slender and not robust as in $A$. karroo. Unlike $A$. karroo, the flowers are not aggregrated into such dense terminal panicles, but tend often to occur in axillary fascicles along the young stems. In addition, the pods are smaller, of a different shape and texture. The species perhaps most likely to be confused with $A$. karroo are $A$. swazica and $A$. exuvialis. However, the bark in both species is different being pale greyish to chestnut or reddish-brown and often peeling off in strips in contrast to the dark brownish-black or reddish-brown rough bark of $A$. karroo. 
A new key to the identification of the species within this complex has been drawn up which makes provision for $A$. torrei. In contrast to the key given by Verdoorn (1.c.), where the first dichotomy was based on pod shape and whether the glands on the pods are conspicuous or not, the emphasis in this key is initially on vegetative characters. This is because pod shape in some of the species is more variable than initially recognized and also because it enables some of the species to be identified when in the flowering or even in the vegetative state. However. even in the presence of pods, it is felt that the vegetative characters used in the key enable certain species to be identified far more readily than by relying on pod characters. All species usually have flowers and pods in various stages of maturity contemporaneously. It may be argued that in the absence of pods it is not possible to establish whether the plant in question is a member of the complex ivith glandular glutinous pods. Whilst this may occasionally be true. it is usually possible and, certainly with a little practice. relatively simple to establish whether or not a plant belongs to this complex.

Young branchlets densely tomentose with spreading white hairs

A. permixla

Young branchlets glabrous, subglabrous. or occasionally very sparingly pubescent:

Mature leaves with 7-20 pinna pairs:

Leaflets glandular-punctate with distinct glands on the lower surface and on margins giving the margin a crenate appearance; pods glabrous or subglabrous. glands inconspicuous A. borleac

Leaflets not glandular-punctate on lower surface and on margins; pods distinctly. although sparingly, pubescent especially on the raised portions over the seeds. glands conspicuous

A. Ierrei

Mature leaves with up to 6 pinna pairs:

Involucel at or near the base of the peduncle; usually only 1 pinna pair. rarely 3 A. nebrownii

Involucel at or above the middle of the peduncle:

Stoloniferous shrubs; leaflets small, up to $4.3 \mathrm{~mm}$ long. $1.5 \mathrm{~mm}$ wide: pods straight or almost so. $4.58 .0 \mathrm{~mm}$ wide A. tenuispina

Non-stoloniferous shrubs; leaflets larger. up to $10 \mathrm{~mm}$ long. $5.1 \mathrm{~mm}$ wide: pods distinctly torulose or only slightly falcate, occasionally straightish; usually broader than above:

Spines slender; midrib and veins usually very conspicuous abaxially; pods slightly to distinctly falcate. occasionally \pm straight, $0.7-1.2 \mathrm{~cm}$ wide. glands conspicuous: seed circular or subcircular

A. swazica

Spines frequently enlarged and swollen basally: midrib and veins inconspicuous abaxially; pods torulose, $4.5-9.0 \mathrm{~mm}$ wide, glands not conspicuous; seed elliptic

A. exuvialis

A. permixta clearly differs from the remainder of the complex in having young branchlets that are usually clothed with a dense indumentum of spreading white hairs, a feature that enables the species to be distinguished even in the vegetative state. $A$ borleae and $A$. torrei differ from the remaining species in having mature leaves with at least seven pinna pairs. $A$. borleae differs from $A$. torrei in having leaflets that are glandular-punctate on the lower surface and on the margins which gives an irregularly crenate appearance. However. the margins of leaflets of $A$. torrei that have been subjected to the ravages of certain insects and sometimes appear crenate must not be confused with leaflets of $A$. borleae. The pods of $A$. borleae are usually glabrous and the glands inconspicuous, whereas in $A$. torrei the pods are distinctly, although sparingly. pubescent especially on the raised portions over the seeds, and the glands are conspicuous. In addition, a large geographical discontinuity separates the two species. $A$. permixta, $A$ borlecue and $A$. torrei can therefore be distinguished from the remainder of the complex and from one another on the basis of vegetative characters alone. 
The position of the involucel on the peduncle is the important character in differentiating $A$. nebrownii from the remaining species. The stoloniferous habit, slender spines and small leaflets distinguish $A$. tenuispina from $A$. swazica and $A$. exuvialis. In $A$. exuvialis the thin bark peels off, but this feature has also been noted on some specimens of $A$. swazica. The spines of A. swazica are slender. whereas in $A$. exuvialis they are often somewhat enlarged and the members of each pair united basally. The conspicuous midrib and veins on the lower surface of the leaflets provide a useful means of identification in dried specimens of $A$. swazica, but it must be mentioned that the midrib and veins are not so conspicuous in living plants. They apparently only become conspicuous when the tissues have dried out. Pod shape also enables the two species to be differentiated. 